Catecholamines in urine and blood pressure recordings of the patient $(n=123)$, her sister $(n=20)$, and her son $(n=5)$ during the observation period

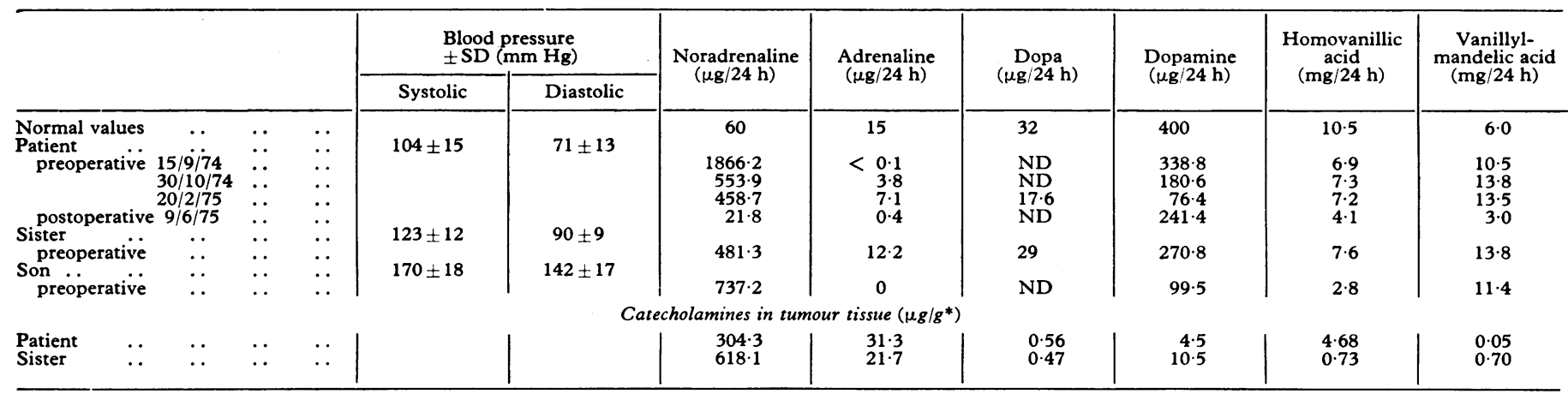

*Except for noradrenaline, all values are within normal range for adrenal glands.

ND $=$ Not determined.

younger child, an 8-year-old boy, who was in hospital with a hypertensive crisis. She complained of weakness, dizziness, nausea, and occasional episodes of hunger and palpitation. Her blood pressure had always been normal. Both her parents died at an early age of unknown causes. For two years her only sister had had hypertension (around 140/100 $\mathrm{mm} \mathrm{Hg}$ ), which we now know was caused by a phaeochromocytoma.

Examination showed an asthenic woman without neurocutaneous abnormalities. Her blood pressure was $140 / 90 \mathrm{~mm} \mathrm{Hg}$ initially; over the next ten days it was always normal (see table). Her pulse rate ranged between 80 and $90 / \mathrm{min}$. The results of numerous routine laboratory investigations were normal. The electrocardiogram was normal. The chest $x$-ray film showed no enlargement of the heart. A percutaneous abdominal angiographic study disclosed symmetrical, highly vascularised masses in the region of both adrenal glands. The bilateral tumours were removed transabdominally. The right one measured $4 \times 3.5 \times 3.5 \mathrm{~cm}$ and the left $5.5 \times 3.5 \times 1.5 \mathrm{~cm}$. Histological examination of the tumours showed a benign encapsulated phaeochromocytoma.

The results of the determination of catecholamines in urine and tumour tissues of the patient, her sister, and her younger son are shown in the table. It should be emphasised that these urinary concentrations of noradrenaline were obtained when our patient's blood pressure and pulse rate were normal, whereas her sister had intermittent and her son continuous hypertension.

\section{Comment}

The absence of hypertension in phaeochromocytoma has been reported several times and variously ascribed to $(a)$ predominant secretion of adrenaline, (b) concomitant dihydroxyphenylalanine (dopa) secretion, (c) inactivation of the noradrenaline within the tumour, $(d)$ myocardial insufficiency, and (e) tolerance of tissue receptors to circulating catecholamines. With the first possibility the beta-adrenergic effects of adrenaline secreted by the tumour dominate the picture, and hypotension or even shock might become the major manifestation. ${ }^{1}$ In such cases urinary and tumour analyses have shown hypersecretion of adrenaline. Louis $e t a^{2}$ suggested that concomitant secretion of dopa might counterbalance the hypertensive action of noradrenaline in phaeochromocytoma. Crout and Sjoerdsma ${ }^{3}$ suggested that there are two types of phaeochromocytoma: small tumours with "low" content of noradrenaline (NA) and adrenaline (A) have a low urinary vanillylmandelic acid (VMA) : NA + A ratio and a low rate of turnover of catecholamines; large tumours with "high" content of NA and A show a high urinary VMA : NA + A ratio and large amounts of NA + A seem to be metabolised directly in the tumour, which might explain the lack of clinical manifestations.

Our patient's pattern of urinary catecholamine excretion shows that only noradrenaline and VMA levels were raised. Thus concomitant secretion of predominantly adrenaline, dopa, or dopamine cannot account for the lack of hypertension. She also had a low urinary VMA : NA + A ratio. Moreover, metabolites were low in the tumour tissue and hence local inactivation was not evident. Thus none of the mechanisms mentioned above apply to our case. As others have suggested, patients with phaeochromocytoma seem to have a different vasoresponse to noradrenaline ${ }^{45}$ : some show pronounced tolerance to endogenous circulating catecholamines since the concentration is sometimes so high as to seem incompatible with life. Our case supports this hypothesis. Furthermore, it is intriguing that, though both her sister and her son showed the same urinary catecholamine excretion pattern, only our patient was always normotensive.

We thank Professor H Käser of the University of Bern for the determination of catecholamines.
1 Page, L B, Raker, J W, and Berberich, F R, American fournal of Medicine, 1969, 47, 648.

${ }^{2}$ Louis, W J, et al, British Medical fournal, 1972, 4, 325.

3 Crout, J R, and Sjoerdsma, A, fournal of Clinical Investigation, 1964, 43, 94.

4 Taubmann, I, Pearson, O H, and Anton, A H, American fournal of Medicine, 1974, 57, 953.

5 Studnitz, W, Pharmacological Reviews, 1966, 18, 645.

(Accepted 20 September 1977)

Medizinische Universitäts-Poliklinik, D-69 Heidelberg, Federal Republic of Germany

A D HO, MD, physician

G FEURLE, MD, consultant in gastroenterology

K-H GLESS, MD, physician

Universitäts-Kinderklinik, D-69 Heidelberg, Federal Republic of Germany

W E BRANDEIS, MD, physician

\title{
Treatment of hyperlipidaemia in patients on chronic haemodialysis
}

Abnormalities of lipid metabolism occur often in patients with chronic renal failure, and these are not reversed by dialysis. ${ }^{1}$ Few attempts have been made to correct the abnormalities, which may at least partly contribute to the accelerated atherosclerosis in these patients. ${ }^{2}$ We have examined the effects of advice on lipid-lowering diets and treatment with slow-release nicotinic acid (Nicangin) in patients with types IIb and IV hyperlipoproteinaemia being treated with dialysis.

\section{Patients, methods, and results}

We had previously measured cholesterol and triglyceride concentrations in 131 patients on chronic haemodialysis (mean age 40.2 years), ${ }^{3}$ of whom $65 \%$ had hyperlipoproteinaemia: type IIa $5 \%$, type IIb $21 \%$, and type IV $39 \%$

Ten patients with type IIb and 10 with type IV were randomly selected for dietary treatment. Their usual diet, assessed by a dietitian, provided a mean of $10.9 \mathrm{MJ}(2600 \mathrm{Kcal})$ daily, half of which were derived from fat (saturated and monounsaturated:polyunsaturated fat ratio 4:1). For one month, as outpatients, they were asked to modify their diet so that fat comprised $40 \%$ of total energy and the ratio of saturated and monounsaturated to polyunsaturated was altered to $1: 1$, while cholesterol was reduced from 675 to $275 \mathrm{mg}$ daily. Carbohydrate was increased (from $40 \%$ to $50 \%$ of total daily calories) to maintain energy balance. After one month they reverted to their previous diet. To determine whether patients were following their lipid-lowering diet we measured linoleic acid as a percentage of total triglyceride fatty acids, as the percentage of linoleic acid increases appreciably when polyunsaturated rather than saturated fatty acids comprise most of the dietary fat. ${ }^{4}$

Three patients with type IIb and three with type IV hyperlipidaemia were recommended to take slow-release nicotinic acid, starting with $0.25 \mathrm{~g}$ four times a day and increasing to $0.5 \mathrm{~g}$, which was continued for 
Mean $( \pm S E M)$ cholesterol and triglyceride concentrations of the diet-treated patients

\begin{tabular}{|c|c|c|c|c|c|c|}
\hline & \multicolumn{3}{|c|}{ Cholesterol $(\mathrm{mmol} / \mathrm{l})$} & \multicolumn{3}{|c|}{ Triglyceride (mmol/l) } \\
\hline & $\begin{array}{l}\text { Before } \\
\text { treat- } \\
\text { ment }\end{array}$ & $\begin{array}{c}\text { After } \\
\text { four } \\
\text { weeks } \\
\text { on } \\
\text { diet }\end{array}$ & $\begin{array}{c}\text { Four } \\
\text { weeks after } \\
\text { reverting } \\
\text { to initial } \\
\text { diet }\end{array}$ & $\begin{array}{l}\text { Before } \\
\text { treat- } \\
\text { ment }\end{array}$ & $\begin{array}{c}\text { After } \\
\text { four } \\
\text { weeks } \\
\text { on } \\
\text { diet }\end{array}$ & $\begin{array}{c}\text { Four } \\
\text { weeks after } \\
\text { reverting } \\
\text { to initial } \\
\text { diet }\end{array}$ \\
\hline \multirow[t]{2}{*}{$\begin{array}{l}\text { Type IIb patients* } \\
(\mathrm{n}=10)\end{array}$} & $\begin{array}{l}8 \cdot 3 \\
+0.48\end{array}$ & $\begin{aligned} & 6.9 \\
+ & 0.51\end{aligned}$ & $\begin{array}{c}7.2 \\
+0.56\end{array}$ & $\begin{array}{r}3.47 \\
+0.36\end{array}$ & $\begin{array}{r}2.62 \\
\pm 0.20\end{array}$ & $\begin{array}{r}2.82 \\
\pm 0.42\end{array}$ \\
\hline & \multicolumn{3}{|c|}{$P<0.01$} & \multicolumn{3}{|c|}{$P<0.01$} \\
\hline $\begin{array}{l}\text { Significance of } \\
\text { differences }\end{array}$ & \multicolumn{3}{|c|}{ NS } & \multicolumn{3}{|c|}{ NS } \\
\hline $\begin{array}{l}\text { Type IV patients } \\
(n=10)\end{array}$ & $\begin{array}{r}5 \cdot 7 \\
+0 \cdot 23 \\
\end{array}$ & $\begin{array}{r}5 \cdot 3 \\
+0.14 \\
\end{array}$ & $\begin{array}{l}5 \cdot 3 \\
.+0 \cdot 29\end{array}$ & $\begin{array}{r}2.97 \\
\pm 0.18 \\
\end{array}$ & $\begin{array}{r}2.07 \\
+: 0.11 \\
\end{array}$ & $\begin{array}{r}2.91 \\
+0.21\end{array}$ \\
\hline $\begin{array}{l}\text { Significance of } \\
\text { differences }\end{array}$ & & & & $\mathbf{P}<$ & $\mathrm{P}<$ & 001 \\
\hline
\end{tabular}

*The means do not include one patient who was later found to have been taking oxymethalone.

NS = Not significant.

six weeks. They continued their usual diets during this period. Cholesterol, triglycerides, lipoproteins, and triglyceride fatty acids were measured by methods described elsewhere. ${ }^{4}$

Mean cholesterol and triglyceride concentrations of the patients on the diet are shown in the table. Linoleic acid as a percentage of total triglyceride fatty acids increased in seven of the ten patients after four weeks on the diet and tended to decrease after they reverted to their old diets.

Persistent flushing caused two of the six patients taking slow-release nicotinic acid to discontinue treatment shortly after starting. The other four had minor side effects at first, and two continued to have some flushing and gastrointestinal symptoms. The predominantly raised lipid concentration fell appreciably in all four (mean percentage fall : cholesterol $20 \%$, triglyceride $35 \%$ ), and rose again to pretreatment values one month after stopping treatment. No appreciable differences in body weight occurred in either group of patients during the experiment.

\section{Discussion}

The cholesterol response to the lipid-lowering diet was striking in the patients with type IIb disease, and triglyceride concentrations fell in those with type IIb and type IV. None of the patients found the diet unacceptable, and measurement of linoleic acid as a percentage of triglyceride fatty acids suggested that most patients adhered to the diet. Interestingly, patients with both type IIb and type IV disease in this investigation responded to an identical diet, which reduced the intake of fat in general and of saturated and monounsaturated fats, but also increased carbohydrate intake.

The slow-release form of nicotinic acid is useful for patients with type IIb and type IV hyperlipoproteinaemia not secondary to renal disease. ${ }^{5}$ Although the drug lowered cholesterol and triglyceride in patients on dialysis, side effects occurred in all six patients, and in two of them the symptoms were severe enough to discontinue treatment. The response to an acceptable modified diet suggests that diet should be the treatment of choice in hyperlipidaemia associated with renal disease. A month is too short to judge whether the improvement in lipid concentrations will be maintained. Longer-term studies are under way to see whether this response can be maintained.

We thank Richard Jelfs and Nigel Rust for their help in lipid estimations and Miss B Lisle for dietary analysis and advice. Dr R A Moore (Nuffield Department of Clinical Biochemistry) was responsible for setting up the GLC method in our laboratories.

1 Bagdade, J D, Porte, D, and Bierman, E L, New England fournal of Medicine, 1968, 279, 181.

${ }^{2}$ Linder, A, et al, New England fournal of Medicine, 1974, 290, 697.

3 Gokal, R, et al, American fournal of Clinical Nutrition. In press.

4 Moore, R A, et al, Clinical Endocrinology, 1977, 7, 143.

- Mann, J I, et al, British fournal of Pharmacology, 1977, 4, 305.

(Accepted 20 September 1977)

Renal Unit, Churchill Hospital, and University of Oxford, Oxford R GOKAL, MRCP, research fellow

J I MANN, DM, university lecturer in social and community medicine

D O OLIVER, FRCP, consultant physician

J G G LEDINGHAM, FRCP, May reader in medicine

R D CARTER, technician

\section{Incidence of cancer in relatives of children with retinoblastoma}

Children with retinoblastoma have an increased risk of developing osteogenic sarcoma, ${ }^{12}$ and members of families containing children with retinoblastoma may be at increased risk of developing cancer at other sites, ${ }^{134}$ though evidence for this has been anecdotal. We have therefore investigated whether families containing an infant with retinoblastoma are prone to cancer.

\section{Methods and results}

With permission from the consultants we examined the files of the Oxford Regional Cancer Registry for all children in the region known to be alive who had been diagnosed as cases of retinoblastoma. The general practitioner in each of these index cases was contacted and permission sought to interview the mother at home. Information obtained on the families included full names of first-, second-, and third-degree relatives, their places of residence since 1952, and their dates of birth. The files of the Regional Cancer Registry and the Oxford Record Linkage Study were then searched for any cases of cancer among the family members who had been resident in the region at any time from 1952. The expected numbers of relatives with cancer were calculated by using the period during which each person was at risk together with published data on the incidence of the disease related to age and sex in the region. ${ }^{5}$

Eleven families were interviewed. In only one index case did the child have bilateral disease. The number of relatives who had developed cancer was significantly higher than expected (see table). Details of the families are given below.

Observed and expected numbers of cases of cancer in relatives resident in Oxford region since 1952

\begin{tabular}{|c|c|c|c|c|c|c|}
\hline \multicolumn{5}{|c|}{ Relationship to index case } & \multirow[b]{2}{*}{$\begin{array}{c}\text { No observed } \\
1 \\
0 \\
1 \\
2 \\
1 \\
0 \\
0 \\
0\end{array}$} & \multirow[b]{2}{*}{$\begin{array}{c}\text { No expected } \\
0.116 \\
0.136 \\
0.199 \\
0.571 \\
0.178 \\
0.283 \\
0.032 \\
0.015\end{array}$} \\
\hline $\begin{array}{l}\text { Great- } \\
\text { Great- } \\
\text { Grandf } \\
\text { Grandr } \\
\text { Father } \\
\text { Mother } \\
\text { Brother } \\
\text { Sister }\end{array}$ & $\begin{array}{l}\text { andf } \\
\text { andn } \\
\text { her } \\
\text { ther } \\
\ldots \\
\ldots \\
\ldots\end{array}$ & $\begin{array}{c}\text { er } \\
\text { her } \\
\ldots \\
\cdots \\
\cdots \\
\cdots \\
\therefore\end{array}$ & $\begin{array}{l}\ldots \\
\because \\
\cdots \\
\because \\
\cdots \\
\cdots\end{array}$ & $\begin{array}{l}\ldots \\
\because \\
\cdots \\
\cdots \\
\cdots\end{array}$ & & \\
\hline $\begin{array}{l}\text { Brother } \\
\text { Sister } \\
\end{array}$ & & & Total & .. & $5^{*}$ & 1.530 \\
\hline \multicolumn{3}{|c|}{ Relative risk } & . & $\cdots$ & \multicolumn{2}{|c|}{$3 \cdot 3$} \\
\hline
\end{tabular}

$* P=0.01$ (One-tailed test used, expectation assumed to be mean of Poisson distribution.)

Family 2-Index case was a girl with retinoblastoma of left eye diagnosed at age 5 and tumour in other eye diagnosed five months later. She was mentally retarded with odd facies and had congenital dislocation of hips. Her paternal great-grandfather had died of lung cancer at age 67 .

Family 4-Index case was a girl with retinoblastoma of left eye diagnosed at age 3. Her maternal grandmother had developed breast cancer at age 58 .

Family 6-Index case was a girl with retinoblastoma of right eye diagnosed at age 1. Her paternal grandfather had developed stomach cancer at age 67, and her paternal grandmother had developed breast cancer at age 68 .

Family 10-Index case was a boy with retinoblastoma of right eye diagnosed at age 1 . His father had died of bronchial carcinoma at age 46 .

During the interviews it became apparent that other members of the 11 families had also developed cancers, although this information was not specifically asked for. In most instances the diagnosis had been made abroad and so could not be verified. Interestingly, however, a distant paternal cousin of the index case in family 6 was said to have had an eye removed in childhood, and a maternal first cousin of another index case was said to have died of cancer of the leg at the age of 13 .

\section{Comment}

The 11 families interviewed were typical of the Oxford region in that they were highly mobile. By confining our analysis to information on relatives resident in the region since 1952 we restricted the data set. Nevertheless, a significant excess of relatives with carcinoma was found.

We thank the consultants and general practitioners for permission to interview the parents, Dr A Barr for allowing us to use the data of the Oxford Regional Cancer Registry, and Miss C Hunt for co-operation. Interviews were conducted by Mrs Yvonne Timms and Mrs Bettine Sutton. 